Indiana Working Papers in South Asian Languages and Cultures

\title{
VARIATION AND CULTURE IN LAIHOLH PSYCHO-COLLOCATIONS
}

\author{
July, 2019 \\ Greyson Yandt \\ ${ }^{1}$ Indiana University Department of Linguistics
}

\begin{abstract}
As shown in previous research, psycho-collocations are a feature of Laiholh, a Tibeto-Burman language in the Kuki-Chin family, that are used to express emotions or physical feelings through metaphor. Because psycho-collocations use metaphor, they experience metaphor variation and can encode cultural information relevant to the understanding of their meanings. The present paper compares the psycho-collocations reported in a study published in 1998 to the psycho-collocations reported by a 21-year-old male speaker of Laiholh from a diaspora community in Indianapolis to show how much these psycho-collocations vary in use, in meaning, and in construction between speakers; furthermore, to show how the deeper cultural information encoded in certain psychocollocations acts as context for a more meaningful understanding.
\end{abstract}

Key Terms - Psycho-collocation, metaphor variation, encoded cultural information

\section{INTRODUCTION}

Laiholh (also Lai, Hakha Lai, or Hakha Chin) belongs to the Kuki-Chin branch of the Sino-Tibetan language family and is primarily spoken in Chin state in Burma/Myanmar (Eberhard, Simons, and Fennig, 2019). There are over 23,000 refugees from Burma/Myanmar in Indiana with 19,000 of those refugees in the Indianapolis area alone, and $71 \%$ of those 19,000 refugees are of the Chin ethnic group (Burmese American Community Institute 2018). This paper addresses a feature of Laiholh called psycho-collocations, and it further addresses how numerous psycho-collocations in Laiholh vary in meaning, construction, or use between different speakers and how certain psychocollocations in Laiholh need cultural context to fully understand their meanings.

A psycho-collocation is a feature of Laiholh described in Kenneth VanBik (1998), which is a feature also described in James Matisoff (1986) for many Southeast Asian languages. A psychocollocation is a set combination of words that expresses an emotion or a state of being in which one of the words carries a direct psychological reference. Thus, psycho-collocations use metaphor-i.e., the understanding of one idea in terms of another - to express abstract ideas of emotions and physical feelings.

Furthermore, because psycho-collocations use metaphor, they are subject to metaphor variation. Zoltán Kövecses (2008) explains that metaphors can vary within a culture due to many factors such as regional variation or change over time. Kövecses (2008) also explains that metaphors can vary across different cultures as well, so, as Chin culture and American culture are different, psycho-collocations in Laiholh may encode unfamiliar cultural information which is necessary context to fully understand the meanings of certain psycho-collocations. 
In the article that is the inspiration for this paper, VanBik (1998) presents a list of psychocollocations in Laiholh, providing literal translations of the phrases alongside their meanings, which was inspired by previous research on psycho-collocations in Matisoff (1986). Furthermore, additional psycho-collocations were collected during this study that are not found in VanBik (1998). The present study investigates these psycho-collocations in the language of a 21-year-old male speaker of Laiholh from the diaspora community in Indianapolis with the following research questions: (1) Is there a difference in the psycho-collocations presented in VanBik (1998) and those in use by young speakers in this community?; (2) For the psycho-collocations in use by the language assistant, do they have the same meanings presented in VanBik (1998)?; (3) Do any of these psycho-collocations encode unfamiliar cultural information as context that is necessary to understand the meaning of the psycho-collocation?

The rest of the paper proceeds as follows. Section 2 presents an overview of collocations, psycho-collocations, and metaphor variation as well as the relationships between those concepts. Section 3 explains how the data was gathered for this study. Section 4 presents items from VanBik (1998) in the romanized orthography with definitions provided by the language assistant, additional items presented by the language assistant, and a discussion about encoded cultural information seen in Laiholh psycho-collocations. Section 5 discusses the data and addresses other notes from the study. Section 6 includes closing remarks.

\section{BACKGROUND}

Matisoff (1986) explains that psycho-collocations are a feature of many Southeast Asian languages and that this feature is not found in Standard Average European languages like English. VanBik says that, based on the volume of work done on psycho-collocations following Matisoff (1986), "it has become clear that 'psycho-collocations' are an essential feature of many languages in Southeast Asia" (VanBik, 1998, p. 201). Including research on Laiholh (VanBik, 1998; 2010), there are several articles dedicated to psycho-collocations in several Southeast Asian languages; for example, Burmese (Vittrant, 2014), Daakaka (Vanuatu) (Prince, 2017), Hmong (Jaisser, 1990), Jingpho (Matisoff, 1986), Lahu (Matisoff, 1986), Malay (Oey, 1990), Thai (Matisoff, 1986), and Tibetan (Matisoff, 1986) are all shown to have psycho-collocations. Psycho-collocations are defined and discussed in Subsection 2.1.

This study builds on the research done in VanBik $(1998 ; 2010)$ by examining how psychocollocations vary in meaning, construction, or use between different speakers. Furthermore, understanding the cultural context behind psycho-collocations where it is unfamiliar also betters the understanding of psycho-collocations, Laiholh, Chin culture, and other relevant cultures. As Kövecses (2008) notes, understanding metaphorical thought is relevant to understanding culture. Variation and culture in metaphors are discussed in Subsection 2.2.

\subsection{Psycho-Collocations}

A collocation is a sequence of words that frequently co-occur, wherein the meaning of the sequence can be computed from the meanings of its component words (Cruse, 1986). A psychocollocation is a type of collocation that contains an explicit psychological reference, often expressing an emotion or physical feeling. VanBik (2010) also describes psycho-collocations as a type of idiomatic expression. Thus, not only do these words frequently co-occur, they appear together to express a meaning separate from (but related to) its constituents using metaphor. 
Matisoff (1986) defines a psycho-collocation as:

a polymorphemic expression referring as a whole to a mental process, quality, or state, one of whose constituents is a psycho-noun, i.e. a noun with explicit psychological reference (translatable by English words like HEART, MIND, SPIRIT, SOUL, TEMPER, NATURE, DISPOSITION, MOOD). The rest of the psycho-collocation contains morphemes (usually action verbs or adjectives) that complete the meaning. (Matisoff, 1986, p. 4)

VanBik (1998) sums up this definition by Matisoff with the following formula: psycho-noun plus psycho-mate equals psycho-collocation. In Laiholh, the psycho-noun is often a body part, usually lung - which is the heart or the liver, depending on context—, whereas the psycho-mate is usually a verb or an adjective that completes the expression (VanBik 1998). Example (1) uses the psycho-noun lung 'heart-liver' as a metaphor for emotions alongside its psycho-mate, rawk 'to break down'. The first row is Laiholh transcribed in romanized orthography, the second row shows Leipzig glossing, and the third row is a free translation.
(1) $\mathrm{ka}$
$\begin{array}{llll}\text { ka } & \text { lung } & \text { a } & \text { rawk } \\ \text { 1SG.POSS } & \text { heart-liver } & \text { 3SG.SUBJ } & \text { break.down }\end{array}$
'I am hurt' / 'I am disappointed'

In English, a close equivalent would be the phrase you broke my heart, in which there is no literal breaking of a heart. In this case, heart is the noun that has explicit psychological reference to the direct object's feelings. Altogether, you broke my heart is a psycho-collocation that means you hurt my feelings. Likewise, in Laiholh, in ka lung a rawk, there is no literal breaking down of a heart-liver. Like heart in English, lung refers to feelings.

\subsection{Variation and Culture in Metaphors}

Metaphor variation within a culture happens for many reasons, such as differential experience, a change in cultural context, or a change in experiential focus (Kövecses, 2008). This variation can be seen across different dimensions, such as across time, social groups, regions, subcultures, styles, and even between individuals. While this variation in metaphor refers to the variation of metaphors used by different speakers, many of the psycho-collocations in this study are used by both the language assistant and VanBik (1998), and the variation in those shared psycho-collocations lies in their differing meanings.

Furthermore, Kövecses (2008) argues that understanding metaphorical thought helps with understanding culture because not all languages and cultures make use of the same metaphors to express similar ideas. ${ }^{1}$ Without the proper cultural context, a metaphor may be harder to fully understand. This is because, as explained by Farzad Sharifian (2013), metaphors can encode cultural information. Like example (1) in Subsection 2.1, Sharifian (2013) also uses you broke my heart, explaining that the use of heart comes from the culture that gave rise to the metaphor and

\footnotetext{
${ }^{1}$ Matisoff (1986) argues that psycho-collocations are "grounded in obvious psychological fact", giving the example that the heart is the universal seat of emotions (p. 15). Sharifian (2013) mentions that the heart is not always the seat of emotions, giving the example of another language, Tok Pisin, which uses belly instead. Kövecses (2008) also argues that the universality of metaphors has been overemphasized. While none of these authors are directly responding to each other, these different perspectives reflect a change in approach to understanding metaphors and inspired this analysis of psycho-collocations.
} 
how that culture conceptualized emotions and feelings. While studying psycho-collocations in Laiholh, I found that the language assistant provided cultural context that was missing from certain items in VanBik (1998), and that additional cultural context was crucial to understanding the meanings of those items. Thus, it is useful to analyze psycho-collocations in Laiholh for their cultural context to better understand Chin culture and differences that would lead to variation in these psycho-collocations.

\section{METHODOLOGY}

The data was elicited from a language assistant over several 1-hour sessions at Indiana University and transcribed into a notebook using the Laiholh romanized orthography. The language assistant is a 21-year-old male speaker of Laiholh who grew up in Tlangkua, Chin State and is a member of the Indianapolis Chin community. The psycho-collocations used as elicitation prompts in this study came from VanBik (1998). The language assistant provided additional psycho-collocations which are also included in the data.

\section{RESULTS}

In total, there are 89 different psycho-collocations in the following data- 83 of which come from VanBik (1998) and 6 of which were provided by the language assistant. For 33 items (see Appendix A), the language assistant provided a definition that is the same as the definition reported in VanBik (1998), which will be discussed in Subsection 4.1. The language assistant was unable to provide a definition for 9 items (see Appendix B), which will be discussed in Subsection 4.2. Subsections $4.3-4.8$ contain a sum of 41 items for which the language assistant had a different definition compared to the definition presented in VanBik (1998). Subsection 4.3 contains 10 items that have synonymous meanings between the language assistant and VanBik (1998) and where the language assistant reported shared intuitions with VanBik (1998), including items that do not differ in meaning but do differ in syntactic construction. Subsection 4.4 contains 4 items for which the language assistant reported a more negative connotation. Subsection 4.5 contains 2 items for which the language assistant reported a more positive connotation. Subsection 4.6 contains 4 items for which the language assistant reported a more intense meaning or extreme variety of the same emotion. Subsection 4.7 contains 21 items for which the language assistant reported a very different definition compared to the definition presented in VanBik (1998) with strong intuitions that the meanings are not the same. Subsection 4.8 contains the last 6 items, which are additional psycho-collocations that were provided by the language assistant. The final subsection, Subsection 4.9, reviews 2 of the previous items, for each of which the language assistant provided an expanded definition that relies on cultural information. For each item, the first row is Laiholh transcribed in romanized orthography, the second row shows Leipzig glossing, and the third row is a free translation. Additionally, some items contain a fourth row, which is an adaptation of the translation given in VanBik (1998).

\subsection{Same Psycho-Collocations}

For 33 of the 83 items (see Appendix A) that come from VanBik (1998), the language assistant provided the same definition as the definition in VanBik (1998). While this study is aimed at the variation in Laiholh psycho-collocations, overlap was expected for many definitions. 


\subsection{Undefined Psycho-Collocations}

For 9 of the 83 items (see Appendix B) that come from VanBik (1998), the language assistant was unable to provide a definition. While this does not show variation in meaning, it does demonstrate that different speakers of Laiholh use and are familiar with different psycho-collocations.

\subsection{Synonymous Psycho-Collocations}

Items (2-11) are psycho-collocations for which the language assistant reported shared intuitions with and had a very similar definition compared to the definition presented in VanBik (1998) as well as psycho-collocations for which the language assistant reported the same definition as VanBik (1998) with a different construction. Each of these items shows a minor variation in the meaning or the construction of the psycho-collocation.

(2) kan thluak a $\quad$ buai bai $^{2}$

1PL.POSS brain 3SG.SUBJ be.messy ?

'We are confused'

(3) mithmai a ngei

eye.face 3SG.SUBJ have

'He has a good reputation'

'He is well respected' (VanBik, 1998, p. 206)

(4) ka hna a ngam

1SG.POSS ear 3SG.SUBJ be.tame

'I am at peace' / 'I am calm'

'I am content / I am not worried' (VanBik, 1998, p. 207)

(5) a or $\quad$ a $\quad$ khu

3SG.POSS throat 3SG.SUBJ smoke

'He can eat anything'

'He / She is gluttonous' (VanBik, 1998, p. 209)

(6) a or a

3SG.POSS throat 3SG.SUBJ be.deep

'He can eat anything'

'He / She is gluttonous' (VanBik, 1998, p. 210)

(7) ka lung/thin/lungthin ${ }^{3}$ a dai

\footnotetext{
${ }^{2}$ For (2), the language assistant did not know what bai meant, but he said it was necessary. VanBik (1998) does not have bai as part of the psycho-collocation - it is just kan thluak a buai in VanBik (1998).

${ }^{3}$ For (7), the language assistant preferred the construction ka thin a dai over the others and especially did not feel like it should be used with lung.
} 
1sG.POSS heart-liver 3SG.SUBJ be.quiet

'I feel calm'

(8) a lung a fak

3SG.POSS heart-liver 3SG.SUBJ ache

'He is hurt' / 'He is sad'

'He / She is bitter' (VanBik, 1998, p. 212)

$\begin{array}{llll}\text { (9) ka } & \text { lung } & \text { a } & \text { mit } \\ \text { 1sG.POSS } & \text { heart-liver } & \text { 3SG.SUBJ } & ?^{4}\end{array}$

'I feel dizzy'

'I feel dizzy looking at you (you are spinning)' (VanBik, 1998, p. 213)

(10) ka lung a tho

1SG.POSS heart-liver 3SG.SUBJ rise

'I am interested'

'I am enthusiastic' (VanBik, 1998, p. 214)

(11) ka lung a ka ton

1SG.POSS heart-liver 3SG.SUBJ 1SG.OBJ meet

'He meets my expectations'

'I am satisfied with him' (VanBik, 1998, p. 215)

\subsection{Pejorated Psycho-Collocations}

Items (12-15) are psycho-collocations for which the language assistant reported a more negative meaning compared to the meaning presented in VanBik (1998). This pejoration shows a variation in meaning.

(12)

$\begin{array}{llll}\text { a } & \text { kaa } & \text { a } & \text { nal } \\ \text { 3SG.POSS } & \text { mouth } & \text { 3SG.SUBJ } & \text { slip }\end{array}$

'He lies a lot'

'He / She is talkative' (VanBik, 1998, p. 208)

(13)

$\begin{array}{llll}\text { an } & \text { hmurka } & \text { a } & \text { sau } \\ \text { 3PL.POSS } & \text { mouth.lip } & \text { 3SG.SUBJ } & \text { be.long }\end{array}$

'They talk when it is not time to talk'

'They are talkative' (VanBik, 1998, p. 208)

(14) ka thin na ka khenh

1SG.POSS heart-liver 2SG.SUBJ 1SG.OBJ hammer

'You make me furious' / 'You piss me off'

'You make me angry' (VanBik, 1998, p. 215)

(15) luak na chuak tuk

\footnotetext{
${ }^{4}$ For (9), the language assistant had the intuition that mit is eye, but VanBik (1998) defines the term as extinguish.
} 
vomit 2SG.OBJ come.out very

'I hate you a lot'

'He is too meddlesome' (VanBik, 1998, p. 220)

\subsection{Ameliorated Psycho-Collocations}

Items (16-17) are psycho-collocations for which the language assistant reported a more positive meaning compared to the meaning presented in VanBik (1998). This amelioration shows a variation in meaning.

a hmai a $\quad$ kau
3SG.POSS face 3SG.SUBJ $\quad$ be.wide
'He is not shy'
'They are daring (negative meaning)' (VanBik, 1998, p. 206)

(17)
ka ha thi na thak
1SG.POSS teeth blood 2SG.SUBJ itch
'I want to squeeze you'
'I can't stand you' (VanBik, 1998, p. 209)

\subsection{Intensified Psycho-Collocations}

Items (18-21) are psycho-collocations for which the language assistant reported a more intense or extreme meaning compared to the meaning presented in VanBik (1998). This increased intensity shows a variation in meaning.

$\begin{array}{llll}\text { ka } & \text { or } & \text { a } & \text { fok } \\ \text { 1SG.POSS } & \text { throat } & \text { 3SG.SUBJ } & \text { protrude }\end{array}$

'I am salivating (thinking about food) ${ }^{5}$

'I want to eat' (VanBik, 1998, p. 209)

(19) $\mathrm{ka}$ or na fok

1SG.POSS throat 2SG.SUBJ protrude

'I am salivating (thinking about you) ${ }^{6}$

'I desire you' (VanBik, 1998, p. 209)

(20)

$\begin{array}{lllll}\text { a } & \text { lung } & \text { ah } & \text { a } & \text { lut } \\ \text { 3SG.POSS } & \text { heart-liver } & \text { LOC } & \text { 3SG.SUBJ } & \text { enter }\end{array}$

'He will remember it (because it went into his heart)'

'He is interested' (VanBik, 1998, p. 213)

(21) ka thin/lung na ka hnemh

1SG.POSS heart-liver 2SG.SUBJ 1SG.OBJ comfort

\footnotetext{
${ }^{5}$ The language assistant gave the context that this is what one might feel when thinking about limes.
}

6 The language assistant said that this is a "perverted" thing to say. 
'You comfort me'7

\subsection{Different Psycho-Collocations}

Items (22-42) are psycho-collocations for which the language assistant reported a different meaning compared to the meaning in VanBik (1998) with strong intuitions that the meanings are not the same. These different meanings and intuitions clearly show variation.

(22)

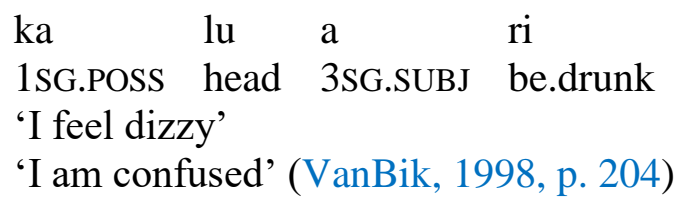

(23)

ka hna a $\quad$ hnok
1SG.POSS ear 3 SG.SUBJ
'I be.tangled
'I feel bothered' (VanBik, 1998, p. 206)

(24)

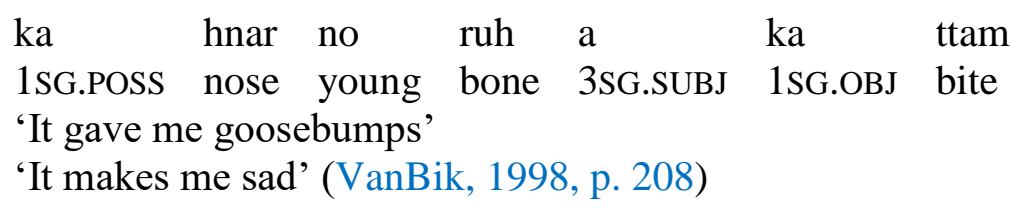

(25)

ka ha thi a thak

1SG.POSS teeth blood 3SG.SUBJ itch

The feeling when one sees a cute baby or animal ${ }^{8}$

'My teeth are on edge' (VanBik, 1998, p. 209)

(26)

$$
\text { ka ha } \quad a^{9} \quad \text { za }
$$

1SG.POSS teeth 3SG.SUBJ tickle

'My teeth tickle' like the unpleasant feeling when one hears iron scraping iron

'I am soured on you' (VanBik, 1998, p. 209)

(27)

a or a $\quad$ vuai
3SG.POss throat 3SG.SUBJ be.satisfied
'He ate enough'
'He is satisfied' (VanBik, 1998, p. 210)

\footnotetext{
${ }^{7}$ While the definitions provided by the language assistant and in VanBik (1998) for (21) are the same, the language assistant reported that this phrase is very poetic and means something even sweeter than comfort. Furthermore, the language assistant provided the term thin hnem tu as what one would use for a romantic partner-literally, it means heart-comforter.

${ }^{8}$ The language assistant explained that (25) has to do with playful aggression, referring to the urge to playfully pinch and squeeze something cute.

${ }^{9}$ Example (26) was often reduced to $k a h a z a$ when spoken, eliding the subject marker.
} 
(28) a hnak kar ah a $\quad$ ka tenh 3SG.POSS ribs between LOC 3SG.SUBJ 1SG.OBJ tuck 'He cares about me' 'He is concerned about me' (VanBik, 1998, p. 210)

(29) a lung a fim

3SG.POSS heart-liver 3SG.SUBJ be.wise

'He can take care of himself'

'He is conscious' (VanBik, 1998, p. 212)

$\begin{array}{llll}\text { ka } & \text { lung } & \text { a } & \text { hring } \\ \text { 1SG.POSS } & \text { heart-liver } & \text { 3SG.SUBJ } & \text { be.green }\end{array}$

'I am doubtful'

'I am suspicious' (VanBik, 1998, p. 212)

(31)

$\begin{array}{llll}\text { a } & \text { lung } & \text { aa } & \text { khiak } \\ \text { 3SG.POSS } & \text { heart-liver } & \text { 3SG.SUBJ.REFL } & \text { decide }\end{array}$

'He has made a decision'

'He / She is determined (decisive)' (VanBik, 1998, p. 212)

(32)

$\begin{array}{llll}\text { ka } & \text { lung } & \text { a } & \text { leng } \\ \text { 1sG.POSS } & \text { heart-liver } & \text { 3SG.SUBJ } & \text { visit } \\ \text { 'I feel nostalgic' } & \\ \text { 'I feel lonely' (VanBik, } & \text { 1998, p. 213) }\end{array}$

(33)

$\begin{array}{llll}\text { kan } & \text { lung } & \text { aa } & \text { lom } \\ \text { 1PL.POSS } & \text { heart-liver } & \text { 3SG.SUBJ } & \text { be.happy }\end{array}$

'We are appreciative'

'We are happy' (VanBik, 1998, p. 213)

$\begin{array}{llll}\text { a } & \text { lung } & \text { a } & \text { puam } \\ \text { 3SG.POSS } & \text { heart-liver } & \text { 3SG.SUBJ } & \text { be.swollen }\end{array}$

'He is ignorant'

'He / She is cocky / stubborn' (VanBik, 1998, p. 213)

(35)

$\begin{array}{llll}\text { a } & \text { lung } & \text { a } & \text { rang } \\ \text { 3SG.POSS } & \text { heart-liver } & \text { 3SG.SUBJ } & \text { be.quick }\end{array}$

'He makes judgments quickly'

'He / She is impatient' (VanBik, 1998, p. 213)

(36)

$\begin{array}{llll}\text { a } & \text { thin } & \text { a } & \text { phang } \\ \text { 3SG.POSS } & \text { heart-liver } & \text { 3sG.SUBJ } & \text { worry }\end{array}$

'He is afraid'

'He is worried' (VanBik, 1998, p. 216)

(37)

na ning a hngal 
2sG.POSS heart 3SG.SUBJ know

'You act in a taboo way'10

'You are presumptuous' (VanBik, 1998, p. 217)

(38)

ka ning a zak

1SG.POSS heart 3SG.SUBJ be.shy

'I am shy'

'I am ashamed' (VanBik, 1998, p. 217)

(39)

ka ai a $\quad$ puang $^{11}$

1SG.POSS strength 3SG.SUBJ ?

'I am frustrated'

'I am extremely angry' (VanBik, 1998, p. 218)

(40)

ka thling na za

1SG.POSS sap 2sG.SUBJ tickle

'You make me ticklish'

'I am soured by you (you look yucky!!)’ (VanBik, 1998, p. 219)

(41) kaa

thlachiat

1SG.SUBJ.REFL spirit.bad

'I do not take revenge'

'I am considerate' (VanBik, 1998, p. 223)

$(42)$

$\begin{array}{lll}\text { thlachiat } & \mathrm{ka} & \text { ruat } \\ \text { spirit.bad } & 1 \mathrm{SG} . \text { SUBJ } & \text { consider }\end{array}$

'I think broadly'

'I am considerate / reluctant (to do anything bad)' (VanBik, 1998, p. 223)

\subsection{Additional Psycho-Collocations}

Items (43-48) are additional psycho-collocations provided by the language assistant that are not found in VanBik (1998). These add to the body of Laiholh psycho-collocations, which will be useful for further studies.

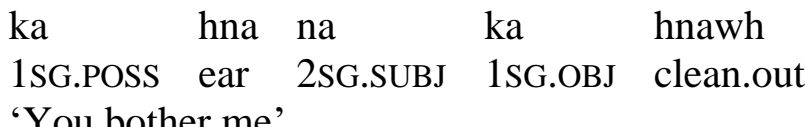

$\begin{array}{llll}\text { a } & \text { ka } & \text { lei } & \text { rawi } \\ \text { 3SG.SUBJ } & \text { 1SG.OBJ } & \text { tongue } & \text { betray } \\ \text { 'He betrayed me' } & & \end{array}$

\footnotetext{
${ }^{10}$ The language assistant felt that (37) concerns breaking cultural norms and violating taboos. He explained that this could be used for someone who disrespects their elders or talks openly about sex.

${ }^{11}$ The language assistant did not understand puang in the context of (39), but VanBik (1998) defines it as flare up.
} 
(45)

$\begin{array}{llll}\text { a } & \text { lung } & \text { aa } & \text { hnem } \\ \text { 3sG.POSS } & \text { heart-liver } & \text { 3SG.SUBJ.REFL } & \text { comfort } \\ \text { 'He comforts himself' } & & \end{array}$

(46)

$\begin{array}{llll}\text { a } & \text { lung } & \text { a } & \text { var } \\ \text { 3SG.POSS } & \text { heart-liver } & \text { 3SG.SUBJ } & \text { be.sharp/be.smart } \\ \text { 'I am smart' } & & \end{array}$

$\begin{array}{lll}\text { na tha a } & \text { bek } \\ \text { 1SG.POSS veins 3SG.SUBJ } & \text { cling } \\ \text { 'You cry too easily' } & \end{array}$

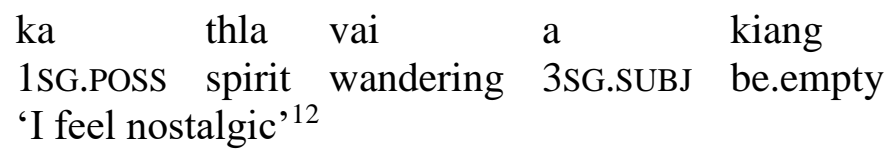

\subsection{Unfamiliar Cultural Context}

Items (49-50) are psycho-collocations from Section 4.7 for which the language assistant provided additional cultural context. The context of the unfamiliar cultural information encoded in these psycho-collocations expands each of their meanings beyond the short phrase in the free translation line.

$$
\begin{aligned}
& \text { kaa thlachiat } \\
& \text { 1SG.SUBJ.REFL } \quad \text { spirit.bad } \\
& \text { 'I do not take revenge' } \\
& \text { 'I am considerate' (VanBik, 1998, p. 223) }
\end{aligned}
$$

(49) is the same as (41). While the language assistant reported that his intuitions were in line with the definition presented in VanBik (1998), the language assistant felt it was missing context. He reported that usage of this psycho-collocation is related to the idea of not wanting to take people to court in Chin culture, preferring to spare others or settle matters personally. This does not have to be deserved or earned by the spared person - the language assistant explained that this is just how things are done. Furthermore, he reported that this cultural metaphor can be used in instances where one is just about to take revenge on a person but then spares the person at the last second.

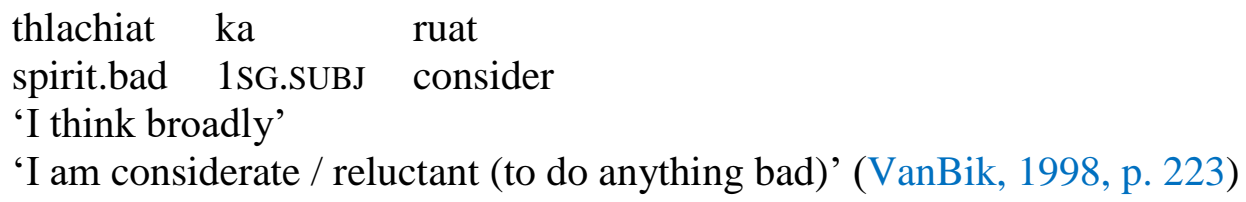

(50) is the same as (42). The language assistant had very different intuitions about the meaning of this psycho-collocation and felt it needed context. The cultural information that the language assistant gave is that it is important and even obligatory to help immediate family in Chin culture.

12 (48) closely resembles (92). 
He explained that this psycho-collocation would describe someone who would help their distant relative even though they are not obligated to do so.

\section{DISCUSSION}

There were two major limitations in this study: (1) the data was provided by just one language assistant, and (2), in reviewing VanBik (1998), I found that I had missed some items.

However, the results do provide answers to the research questions presented in the Introduction. Is there a difference in the psycho-collocations presented in VanBik (1998) and those in use by young speakers in the diaspora community in Indianapolis? As evidenced by the results in Section 4.2, the answer is yes. Even though the language assistant was familiar with 74 of the 83 psycho-collocations (as shown in Sections 4.1 and 4.3-4.8) from VanBik (1998), he was still unfamiliar with 9 of them, which demonstrates the variation in psycho-collocations used between different speakers. For the psycho-collocations in use by the language assistant, do they have the same meanings presented in VanBik (1998)? As evidenced by the results in Section 4.3 through Section 4.7, the answer is that they do not always have the same reported meanings, though the language assistant provided a radically different meaning for only a few psycho-collocations. Only 33 of the 83 psycho-collocations presented in VanBik (1998) had an identical meaning for the language assistant. Do any of these psycho-collocations encode unfamiliar cultural information as context that is necessary to understand the meaning of the psycho-collocation? As evidenced by the results in Section 4.9, the answer is yes.

Additionally, this study left me with a few notes from the language assistant. (1) He taught me about khoih, which is used in (70). We had multiple discussions about what khoih means, which is not simply provoke. It is used for peeling something off as in peeling off a scab but not peeling off a sticker. He also used it in cangai a khoih, which is to catch crabs in their holes. It can be used for removing seeds from apples but not removing the pit from an avocado, and it is also used as khoih! to mean give it to me! (2) When I asked if there was an equivalent of the folkloric mare-a malicious being that sits on the chest of sleeping people, related to the condition of sleep paralysis - in Laiholh, he told me that it is called mumangnenh, which is elucidated in mang 'dream' and nenh 'pressure'. (3) He told me that he was excited to share our work because he said that not a lot of speakers of Laiholh think about these phrases literally but also that, for many of these phrases, there are no literal counterparts. (4) Most importantly, toward the beginning of the study, when eliciting (23), the language assistant told me that it was a psycho-collocation that he used to use, and he told me that it made him feel nostalgic but also made him feel sad that he had been losing part(s) of his language. This moment inspired me more than any other to work with psycho-collocations, especially in recording more of them, and there were many others that he said that he had used in the past but no longer used. Though, because many of their meanings do not have alternate ways to be expressed, he also felt that many of them were not in danger of being lost. Still, it led to the question: Which psycho-collocations are being lost?

\section{CONCLUSION}

Altogether, the results of this study are evidence that psycho-collocations in Laiholh show variation akin to metaphor variation in both meaning and construction between speakers, that different speakers may be unfamiliar with certain psycho-collocations, and that psychocollocations can encode extensive cultural information. 
In the future, this data could be used to elicit data from more speakers of Laiholh for an even better understanding of how psycho-collocations vary across speakers. Section 4.8 aids this possibility by providing additional psycho-collocations to test thanks to the language assistant. This study also does not determine why such variation exists. Do psycho-collocations vary between speakers of Laiholh because of differences in age? Because of differences in dialect? Because of another factor? If psycho-collocations vary in usage, do certain groups have unique psycho-collocations? Furthermore, is Kenneth VanBik familiar with the psycho-collocations provided by the language assistant in Section 4.8? If not, that is greater evidence for variation in use of psycho-collocations. Do the psycho-collocations shared by the language assistant and Van Bik (1998) vary among other speakers? Would interviewing more speakers of Laiholh reveal more psycho-collocations? Are certain psycho-collocations more resistant to variation than others? Are there other psycho-collocations that encode unfamiliar cultural information? Outside of Laiholh, do psycho-collocations in other languages vary in the same ways? For the same reasons? These questions will be addressed and studied in future research.

\section{ACKNOWLEDGEMENTS}

I would like to thank J.C. Wamsley for helping me put the finishing touches on this paper, Samson Lotven for his feedback and for inspiring me to revisit this paper in the first place, Professor Kelly Berkson for the field methods class where this paper was born, to all of the language assistants for making that class' study of Laiholh possible, and especially to the language assistant who worked with me and made this study possible.

\section{REFERENCES}

Burmese American Community Institute (2018). "Overview," Burmese American Community Institute, thebaci.org/ about-us/overview/.

Cruse, D. A. (1986). "Syntagmatic delimitation," in Lexical semantics. Cambridge University Press.

Eberhard, D.; Simons, G.; and Fennig, C. (eds.) (2019). Ethnologue: Languages of the World. Twenty-second edition. Dallas, Texas: SIL International.

Jaisser, A. (1990). "DeLIVERing an introduction to psycho-collocations with SIAB in Hmong," Linguistics of the Tibeto-Burman area, 13(1), 159-178.

Kövecses, Z. (2008). "Universality and variation in the use of metaphor," Selected Papers from the 2008 and 2007 Stockholm Metaphor Festivals.

Matisoff, J. (1986). "Hearts and minds in Southeast Asian languages and English: an essay in the comparative lexical semantics of psycho-collocations," Cahiers de Linguistique Asie Orientale, 15(1), 5-57.

Prince, K. von (2017). "Dozing eyes and drunken faces," Studies in Language, 41(2), 502-520.

Oey, E. (1990). Psycho-collocations in Malay. Linguistics of the Tibeto-Burman area 13(1), 141158.

Sharifian, F. (2013). "Cultural linguistics and intercultural communication," in Language and intercultural communication in the New Era. Routledge.

VanBik, K. (1998). "Lai psycho-collocation," Linguistics of the Tibeto-Burman area, 21(1), 201233. 
VanBik, K. (2010). "The Syntax of Psycho-collocations in Hakha Lai," Linguistics of the TibetoBurman area, 33(2), 137-150.

Vittrant, A. (2013). "16 Psycho-collocational expressives in Burmese," in The aesthetics of grammar: Sound and meaning in the languages of mainland southeast Asia. Cambridge University Press.

\section{APPENDIX A}

Items (51-83) are psycho-collocations that have the same definition reported by the language assistant and in VanBik (1998).

(51)

$\begin{array}{llll}\text { na } & \text { thluak a } & \text { chia } & \text { tuk } \\ \text { 2SG.POSS brain } & \text { 3SG.SUBJ } & \text { be.bad } & \text { very } \\ \text { 'You are very unintelligent' } & & \end{array}$

(52)

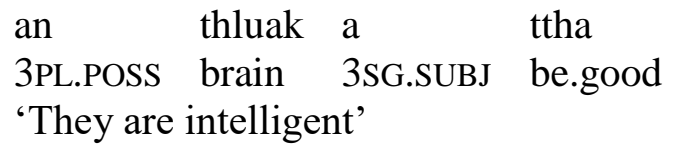

(53)

$\begin{array}{llll}\text { ka } & \text { mit } & \text { a } & \text { ku } \\ \text { 1sG.POSS eye } & \text { 3SG.SUBJ } & \text { be.sleepy } \\ \text { 'I am sleepy' } & & \end{array}$

$\begin{array}{llll}\text { ka } & \text { mit } & \text { a } & \text { thi } \\ \text { 1SG.POSS } & \text { eye } & \text { 3SG.OBJ } & \text { die } \\ \text { 'I want it' } & & & \end{array}$

$\begin{array}{llll}\text { an } & \text { hmai } & \text { a } & \text { panh } \\ \text { 3PL.POSS } & \text { face } & \text { 3SG.SUBJ } & \text { be.bright }\end{array}$

'They are cheerful'

$\begin{array}{llll}\text { a } & \text { hmai } & \text { a } & \text { chia } \\ \text { 3SG.POSS } & \text { face } & \text { 3sG.SUBJ } & \text { be.bad }\end{array}$

'He is unhappy'

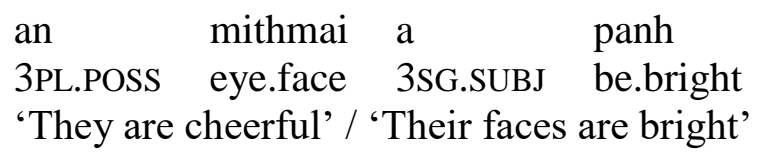

$\begin{array}{llll}\text { a kaa a } & \text { dak } \\ \text { 3SG.POSS mouth } & \text { 3SG.SUBJ } & \text { quack } \\ \text { 'He is talkative' } & & \end{array}$
a kaa a thaw
3SG.POSS mouth 3SG.SUBJ be.delicious
'His appetite is good' 


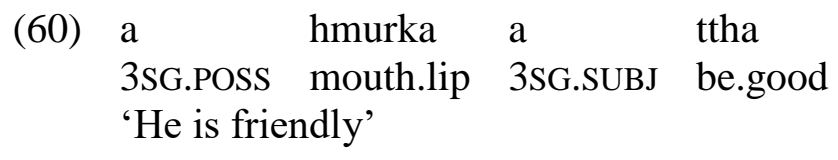

(61) $\mathrm{ka}$ di a riam

1SG.POSS drool 3SG.SUBJ cut

'I am satisfied'

(62) ka lung a rawk

1SG.POSS heart-liver 3SG.SUBJ break.down

'I am hurt' / 'I am disappointed' 13

(63) a lung/thin aa domh

3SG.POSS heart-liver 3SG.SUBJ.REF hold

'He is worried'

(64) ka lung a dong

1SG.POSS heart-liver 3SG.SUBJ end

'I give up'

(65) ka lung a fiang/piang

1SG.POSS heart-liver 3SG.SUBJ be.clear

'I understand'

(66) ka lungre a thai

1SG.POSS $?^{14} \quad 3$ SG.SUBJ know

'I am worried'

(67) ka lung a tling

1SG.POSS heart-liver 3SG.SUBJ be.complete

'I agree'

(68) $\mathrm{ka} \quad$ lung a vaivuan

1SG.POSS heart-liver 3SG.SUBJ wander.float

'I am confused'

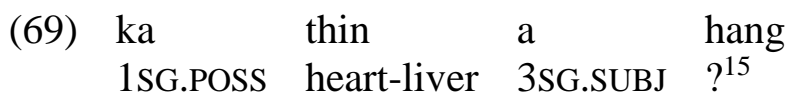

'I am angry'

${ }^{13}$ Item (62) is identical to item (1) in Section 2.

${ }^{14}$ The language assistant did not know what lungre in item (17) meant, but he did not agree with the definition of heart-dry given in VanBik (1998).

${ }^{15}$ The language assistant did not know what hang meant in the context of item (21). VanBik (1998) provides the definition become liquid for hang. 


(70) $\mathrm{ka}$ thin
1sG.POSS heart-liver
You provoke me.
(76) $\mathrm{ka} \quad \operatorname{ning}^{17}$ a ttih
1SG.POSS *heart 3SG.SUBJ be.afraid
'I am afraid'
(77) $\mathrm{ka}$ tha a ba
1SG.POSS veins 3SG.SUBJ be.tired
'I am tired'
(78) $\mathrm{ka}$ tha a thu 1SG.POSS veins 3SG.SUBJ stink 'I am lazy'
(79) $\mathrm{ka}$ tha a chia 1SG.POSS veins 3sG.SUBJ be.bad 'I am discouraged'
(80) ka tha a thawng 1SG.POSS veins 3SG.SUBJ be.strong

\footnotetext{
${ }^{16}$ The word khoih is discussed in the Conclusion. The language assistant described it as to peel off (a scab).

${ }^{17}$ VanBik (1998) notes that ning comes from Proto-Tibeto-Burman and that it is only found in this form in psychocollocations. This use of ning can also be found in items (37) and (38).
} 
'I am strong'

(81)

$\begin{array}{llll}\text { ka } & \text { zaang } & \text { na } & \text { fak } \\ \text { 1SG.POSS } & \text { strength } & \text { 2SG.SUBJ } & \text { be.painful } \\ \text { 'I pity you' } & \end{array}$

(82)

$\begin{array}{llll}\text { ka } & \text { thling a } & \text { kik } \\ \text { 1sG.POSS } & \text { sap } & \text { 3SG.SUBJ } & \text { be.cold }\end{array}$

'I feel afraid of heights'

(83)

$\begin{array}{lll}\text { ka thling } & \text { a } & \text { za } \\ \text { 1sG.POSS sap } & \text { 3SG.SUBJ } & \text { tickle } \\ \text { 'I am ticklish' } & & \end{array}$

\section{APPENDIX B}

Items (84-92) are psycho-collocations with which the language assistant was unfamiliar and was thus unable to provide a definition. Instead, the following items are shown with the definitions presented in VanBik (1998).

$\begin{array}{llll}\text { kan } & \text { thluak } & \text { a } & \text { bu } \\ \text { 1PL.POSS } & \text { brain } & \text { 3SG.SUBJ } & \text { be.crowded }\end{array}$

'We are not unintelligent' (VanBik, 1998, p. 205)

(85)

$\begin{array}{lll}\text { mitpar } & \text { a } & \text { ngei } \\ ? & \text { 3SG.SUBJ } & \text { have }\end{array}$

'He is fickle (=a womanizer)' (VanBik, 1998, p. 205) ${ }^{18}$

(86)

$\begin{array}{llll}\text { a } & \text { lung } & \text { a } & \text { hmeh } \\ \text { 3SG.POSS } & \text { heart-liver } & \text { 3SG.SUBJ } & \text { press } \\ \text { 'It makes him sad' (VanBik, 1998, } & \text { p. 212) }\end{array}$

(87)
a lung aa sak
3SG.POSS heart-liver 3SG.SUBJ.REFL be.swollen

'He / She is comforting himself / herself' (VanBik, 1998, p. 214)
$\mathrm{ka}$
lung
a
thi
1SG.POSS heart-liver 3SG.SUBJ die

\footnotetext{
18 The language assistant reported that he had heard (77) before; however, he did not have a strong intuition as to what it means. Furthermore, he was unsure of the definition of mitpar. It seems to be a combination of eye and flower, but the language assistant explained that it may have something to do with eyebrows or eyelashes.
} 
'I am settled' (VanBik, 1998, p. 214) ${ }^{19}$

(89)

ka lung a te

1SG.POSS heart-liver 3SG.SUBJ fork/branch

'I am indecisive' (VanBik, 1998, p. 215)

(90)

a thin a tha

3SG.POSS heart-liver 3SG.SUBJ be.good

'He is good' (VanBik, 1998, p. 216) ${ }^{20}$

(91)
a un aa thu
3SG.POSS sulking 3SG.SUBJ.REFL stink
'He / She is touchy' (VanBik, 1998, p. 221)

(92) ka thla a vai

1SG.POSS spirit 3SG.SUBJ wander

'I feel lonely' (VanBik, 1998, p. 223) ${ }^{21}$

${ }^{19}$ The language assistant had heard of (80), but he did not know what it meant.

20 The opposite of (75), the language assistant explained that, while (90) made sense, he had never heard this used before.

${ }^{21}$ (84) stood out because the language assistant reported feeling spooked by the psycho-collocation, which gave him goosebumps and made him imagine his spirit leaving his body. 